\title{
HSP20 phosphorylation and airway smooth muscle relaxation
}

\author{
This article was published in the following Dove Press journal: \\ Cell Health and Cytoskeleton \\ 18 June 2009 \\ Number of times this article has been viewed
}

\author{
Mariam $\mathrm{Ba}^{\prime}$ \\ Cherie A Singer' \\ Manoj Tyagi ${ }^{2}$ \\ Colleen Brophy ${ }^{3}$ \\ Josh E Baker ${ }^{4}$ \\ Christine Cremo ${ }^{4}$ \\ Andrew Halayko ${ }^{5}$ \\ William T Gerthoffer ${ }^{2}$ \\ 'Department of Pharmacology, \\ University of Nevada School \\ of Medicine, Reno, NV, USA; \\ ${ }^{2}$ Department of Biochemistry \\ and Molecular Biology, University \\ of South Alabama, Mobile, AL, USA; \\ ${ }^{3}$ Harrington Department \\ of Biochemistry, Arizona State \\ University, Tempe, AZ, USA; \\ ${ }^{4}$ Department of Biochemistry \\ and Molecular Biology, University \\ of Nevada, Reno, NV, USA; \\ ${ }^{5}$ Departments of Physiology \\ and Internal Medicine, University \\ of Manitoba, Winnipeg, MB, Canada
}

\begin{abstract}
HSP20 (HSPB6) is a small heat shock protein expressed in smooth muscles that is hypothesized to inhibit contraction when phosphorylated by cAMP-dependent protein kinase. To investigate this hypothesis in airway smooth muscle (ASM) we showed that HSP20 was constitutively expressed as well as being inducible in cultured hASM cells by treatment with $1 \mu \mathrm{M}$ isoproterenol or $10 \mu \mathrm{M}$ salmeterol. In contrast, a mixture of proinflammatory mediators (interleukin-1 $\beta$, tumor necrosis factor $\alpha$, and interferon $\gamma$ ) inhibited expression of HSP20 by about $50 \%$ in 48 hours. To determine whether phosphorylation of HSP20 is sufficient to induce relaxation, canine tracheal smooth muscle was treated with a cell permeant phosphopeptide that mimics the phosphorylation of HSP20. The HSP20 phosphopeptide antagonized carbacholinduced contraction by $60 \%$ with no change in myosin light chain phosphorylation. Recombinant full length HSP20 inhibited skeletal actin binding to smooth muscle myosin subfragment 1 (S1), and recombinant cell permeant TAT-HSP20 S16D mutant reduced F-actin filaments in cultured hASM cells. Carbachol stimulation of canine tracheal smooth muscle tissue caused redistribution of HSP20 from large macromolecular complexes (200-500 kDa) to smaller complexes ( $<60 \mathrm{kDa})$. The results are consistent with HSP20 expression and macromolecular structure being dynamically regulated in airway smooth muscle. HSP20 is upregulated by beta agonists and downregulated by proinflammatory cytokines. HSP20 is phosphorylated in vivo in a cAMP-dependent manner and the phosphorylated form promotes airway smooth muscle relaxation, possibly through depolymerization of F-actin as well as inhibition of myosin binding to actin.
\end{abstract}

Keywords: actin, bronchodilator, forskolin, myosin, salmeterol, trachea

\section{Introduction}

HSP20 (HSPB6) is a $20 \mathrm{kDa}$ stress-inducible protein expressed in vascular smooth muscle that is phosphorylated at $\mathrm{Ser}^{16}$ by cAMP-dependent protein kinase (PKA) in response to treatment with vasodilators. ${ }^{1-3}$ Binding of phosphorylated HSP20 to smooth muscle contractile proteins is thought to inhibit force production. ${ }^{2,4}$ This was convincingly shown by transduction of a cell-permeant HSP20 phosphopeptide mimic and full length cell-permeant phosphorylated HSP20 protein into intact vascular smooth muscle which induced relaxation. ${ }^{5-7}$ Phosphorylation of HSP20 is thought to be part of the mechanism of action of nitrovasodilators and $\beta$-adrenergic agonists. Since $\beta$-adrenergic agonists are mainstays of asthma therapy, we sought to investigate the mechanism by which HSP20 might act as a bronchodilator protein as previously described by others. ${ }^{8}$ One hypothesis is that HSP20 is phosphorylated by either PKA or PKG at Ser ${ }^{16}$ making it a dominant inhibitor of smooth muscle contraction by disrupting F-actin structure. An alternate, but not mutually exclusive,
Correspondence: William T Gerthoffer Department of Biochemistry and Molecular Biology, University of South Alabama, College of Medicine, Mobile, AL 36688, USA

Tel + I 25I 4606856

Fax + I 25I 4606850

Email wgerthoffer@usouthal.edu 
view is that a Troponin I-like motif at amino acids 110-123 (GFVAREFHRRYRL) is sufficient to suppress contraction of smooth muscle by inhibiting actin binding to myosin., ${ }^{49}$ Another possibility is that these motifs simultaneously suppress force development and antagonize preexisting contraction of airway smooth muscle.

Cyclic nucleotide-induced relaxation of vascular, uterine, and bladder smooth muscle depends on HSP20 expression and phosphorylation of HSP20. ${ }^{10-12}$ Whether this is the case in airway smooth muscle is not known. Because proinflammatory agents including tumor necrosis factor- $\alpha(\mathrm{TNF} \alpha)$, interleukin-1 $\beta$ (IL-1 $\beta$ ), and interferon- $\gamma$ (IFN $\gamma$ ) are known to enhance contraction or antagonize relaxation of airway smooth muscle, ${ }^{13,14}$ we tested for variability in HSP20 expression as a contributor to altered airway reactivity.

Our results show that HSP20 expression and its macromolecular structure are dynamically regulated in airway smooth muscle. HSP20 is upregulated by beta agonsts and downregulated by proinflammatory cytokines. HSP20 is phosphorylated in vivo in a cAMP-dependent manner and the phosphorylated form promotes airway smooth muscle relaxation, possible through depolymerization of F-actin as well as inhibition of myosin binding to actin.

\section{Materials and methods}

\section{Tissue preparation and measurement of contraction}

Adult mongrel dogs of either sex and weanling pigs were sacrificed after ketamine preanesthesia by barbiturate overdose. All procedures were approved by institutional animal care committees at the University of Nevada, Reno or University of South Alabama. Canine and porcine tracheae were excised and placed in physiological salt solution (PSS) composed of (mM): $\mathrm{NaCl}, 140 ; \mathrm{KCl}, 4.7 ; \mathrm{MgSO}_{4}, 1.2 ; \mathrm{CaCl}_{2}, 2.5 ; \mathrm{Na}_{2} \mathrm{HPO}_{4}$, 1.2; $\mathrm{Na}_{2} \mathrm{EDTA}, 0.02 ; 3$-(N-morpholino) propanesulfonic acid, 2.0; and D-glucose, 5.6; $\mathrm{pH}$ 7.4. Tracheal smooth muscle was dissected free of the tunica fibrosa and epithelium, and was cut into strips (canine $-2 \times 10 \mathrm{~mm}$; porcine $-1 \times 4$ ) Muscle strips were incubated $30 \mathrm{~min}$ at $37^{\circ} \mathrm{C}$ in oxygenated PSS, then stimulated twice for 5 min with $1 \mu \mathrm{M}$ carbachol (canine) or $1 \mu \mathrm{M}$ methacholine (porcine). Muscle length was adjusted to a standard reference length by stretching the tissue until passive tension was equal to the maximum active tension induced by muscarinic agonist and then allowing the muscle to stress relax for $5 \mathrm{~min}$. The muscles were then shortened until passive tension equaled $10 \%$ of the active tension induced by carbachol or methacholine. ${ }^{15} \mathrm{~A}$ similar protocol was followed using porcine tracheal strips except that methacholine was used as the agonist instead of carbachol.

\section{Tissue uptake of fluorescein-labeled cell-permeant HSP20 phosphopeptide}

To assess tissue distribution of peptides with a protein transduction motif an N-terminal fluorescein-labeled HSP20 phosphopeptide (Fluorescein-YARAAARQARAWLRRAS( $\left(\mathrm{PO}_{3}\right)$ APLPGLK) was synthesized by Biopeptide, Inc (San Diego, CA). Thin tracheal smooth muscle strips $(0.2 \mathrm{~mm} \times 2 \mathrm{~mm})$ were incubated with $1 \mathrm{mM}$ fluorescein-tagged peptide for $20 \mathrm{~min}$ in physiological salt solution followed by a $10 \mathrm{~min}$ washout to clear the extracellular space of peptide. Control tissues incubated in PSS alone were treated identically and used to measure background fluorescence. Tissues were quickly embedded in optimum cutting temperature medium (OCT) containing DAPI and sectioned on a cryostat. Sections were mounted on glass slides and fluorescence distribution through the muscle strips was visualized using a Zeiss AxioCam HRc digital camera (Carl Zeiss MicroImaging, Inc., Thornwood, NY) and Axiovision 4.1 software (Carl Zeiss MicroImaging, Inc.).

\section{Cell culture and drug treatments}

Human airway smooth muscle (hASM) cells were obtained from macroscopically healthy segments of 2 nd -4 th generation lobar or main bronchus of patients undergoing lung surgery in accordance with the procedures approved by the Ethics Committee of the University of Manitoba, Winnipeg, Canada. Primary cultures were established from dissected enzyme-dissociated hASM bundles as previously described ${ }^{16,17}$ hASM cells were maintained in a humidified $5 \% \mathrm{CO}_{2}$ atmosphere at $37{ }^{\circ} \mathrm{C}$ in M199 supplemented with $5 \%$ newborn calf serum, $0.5 \mathrm{ng} / \mathrm{ml}$ epidermal growth factor, and $2 \mathrm{ng} / \mathrm{ml}$ fibroblast growth factor. Primary cultures from passages four through nine were used for these experiments. When the cultures reached confluence, they were growtharrested for $24-48$ hours in a 50:50 mix of serum-free Ham's F12 and DMEM containing $5 \mu \mathrm{g} / \mathrm{ml}$ insulin, $5 \mathrm{ug} / \mathrm{ml}$ transferin, and $5 \mathrm{ng} / \mathrm{ml}$ selenious acid (ITS Premix; BD Biosciences, San Jose, CA).

To test for dynamic changes in HSP20 expression growth arrested cells were stimulated with $20 \mathrm{ng} / \mathrm{ml} \mathrm{TNF} \alpha$ alone, a mixture of $10 \mathrm{ng} / \mathrm{ml}$ each, IL- $1 \beta, \mathrm{TNF} \alpha$, and IFN $\gamma$, $1 \mu \mathrm{M}$ isoproterenol or $10 \mu \mathrm{M}$, salmeterol for times ranging from 0-48 hours. Untreated cells were exposed to appropriate solvent controls. Total protein was extracted as described below and HSP20 expression analyzed by Western blotting. 


\section{Analysis of HSP20 protein expression}

Cells in culture treated with cytokines or $\beta$-agonists were scraped into a total protein extraction buffer composed of $2 \%$ (w/v) sodium dodecyl sulfate, $60 \mathrm{mM}$ Tris, $\mathrm{pH}$ 7.5, $1 \mathrm{mM}$ [ethylene-bis(oxyethylenenitrilo)]-tetraacetic acid ((EGTA), $1 \mathrm{mM} \mathrm{Na}{ }_{2}$ ethylenediamine tetraacetic acid $\left(\mathrm{Na}_{2}\right.$ EDTA), $5 \mathrm{mM} \mathrm{NaF}, 1 \mathrm{mM}$ 4-(2-Aminoethyl) benzenesulfonyl fluoride hydrochloride (AEBSF). Homogenates were sonicated to disrupt DNA and then clarified by centrifugation at $10,000 \times \mathrm{g}$ for $10 \mathrm{~min}$ at $4{ }^{\circ} \mathrm{C}$. The protein content of each SDS extract was assayed by the bicinchoninic acid method. Proteins in the SDS extract were resolved under reducing conditions by SDSPAGE (12\% acrylamide) and transferred to pure nitrocellulose in $25 \mathrm{mM}$ Tris, $192 \mathrm{mM}$ glycine, 10\% methanol using a Genie electrophoresis unit (Idea Scientific, Minneapolis, $\mathrm{MN})\left(24 \mathrm{~V}, 1.5\right.$ hours, $\left.4{ }^{\circ} \mathrm{C}\right)$. The blots were probed with rabbit anti-HSP20 polyclonal antibody (SPA-796; Stressgen, Ann Arbor, MI) and goat anti-rabbit-IgG Alexa680 secondary antibody (A-21076; Invitrogen, Carlsbad, CA). Images of immunoblots were obtained using a LI-COR Odyssey infrared imaging system (LI-COR Biosciences, Lincoln, NE). Densitometric analysis of immunoreactive bands was performed with Version 1.2 of the Odyssey application software (LI-COR Biosciences). All densitometric data were obtained from samples loaded onto gels within the linear range of the detection system as determined in preliminary studies. Recombinant HSP20 (30-100 ng/lane) was included on some gels as a reference standard. Blots were routinely reprobed with anti-cycloxygenase-1 (anti-COX-1) polyclonal antibody (sc-19998; Santa Cruz Biotechnology, Santa Cruz, CA) and detected with goat anti-rabbit-IgG IRDye 800 secondary antibody (A-21076; Invitrogen). COX-1 served as a loading control and an invariant reference protein (Figure 1).

\section{HSP20 phosphorylation}

Phosphorylation of HSP20 at Ser ${ }^{16}$ was measured in cultured hASM cells by immunoblotting and detection with $\mathrm{Ser}^{16}$ phosphospecific antibodies (a gift of Dr Colleen Brophy). Protein extracts were analyzed by SDS-PAGE and Western blotting. HSP20 phosphorylated at Ser ${ }^{16}$ was assayed by immunoblotting and detection with HSP20 phosphoserine primary antibody $^{2}$ and goat-anti-rabbit Alexa 680 secondary antibody.

\section{Myosin light chain phosphorylation}

Muscle strips were frozen in cold $\left(-80^{\circ} \mathrm{C}\right)$ acetone containing $5 \%(\mathrm{w} / \mathrm{v})$ trichloroacetic acid (acetone/TCA). After $30 \mathrm{~min}$ in acetone/TCA the strips were transferred to pure acetone at room temperature for $30 \mathrm{~min}$. Myosin light chains were extracted by vigorous stirring in $50 \mu \mathrm{l} / \mathrm{mg}$ muscle of $6 \mathrm{M}$ urea, $120 \mathrm{mM}$ tris hydroxyaminomethane, $10 \mathrm{mM}$ DTT, $10 \mathrm{mM}$ EGTA, $1 \mathrm{mM}$ $\mathrm{Na}_{2}$ EDTA, and $5 \mathrm{mM} \mathrm{NaF}, 1 \times$ Complete $^{\circledR}$ protease inhibitor cocktail (11 836170 001; Roche, Nutley, NJ). Extracted proteins were separated on nondenaturing polyacrylamide gels (12\% acrylamide) gels without SDS (BioRad, Hercules, CA). Proteins were transferred to nitrocellulose, and $20 \mathrm{kDa}$ myosin light chains were visualized by immunostaining with rabbit anti-myosin light chain polyclonal antibodies. Goat anti-rabbit secondary antibodies conjugated to Alexa 680 were visualized with a LI-COR Odyssey scanner. Fractional phosphorylation was determined by scanning densitometry of samples loaded in the linear range of detection for both nonphosphorylated and monophosphorylated $20 \mathrm{kDa}$ myosin light chain.

\section{Labeling actin filaments with fluorescent phalloidin}

Actin filaments in cultured hASM cells were visualized by staining with 5 units/ml Texas Red-X conjugated phalloidin (T7471; Invitrogen). hASM cells were cultured for 48 hours in Ham's F12/DMEM + ITS premix on $22 \mathrm{~mm}$ glass coverslips coated with type I collagen (BD Biosciences). To test for an effect of HSP20 on actin filaments cells were treated for two hours with nothing, $10 \mu \mathrm{M}$ cytochalasin D, $1 \mu \mathrm{M}$ TAT-HSP20 wild type or $1 \mu \mathrm{M}$ TAT-HSP20 S16D phosphomimetic proteins. Cells were fixed in 4\% paraformaldehyde for $10 \mathrm{~min}$, permeabilized with $0.1 \%$ Triton X-100 for $5 \mathrm{~min}$, blocked in $1 \%$ bovine serum albumin (BSA), incubated with 5 units/ml Texas Red-X conjugated phalloidin and counter stained with DAPI (Vectashield, Vector Laboratories Inc., Burlingame, CA). Phalloidin-labeled actin filaments were visualized by wide-field epifluorescence microscopy. Fluorescence images were processed post-acquisition with Image J 1.38x (NIH) software to set the threshold and maximum pixel intensity based on the untreated control cells. Images of cells in all treatment groups were processed using the same microscope and software settings in order to detect relative changes in phalloidin-labeled F-actin fluorescence.

\section{Expression and purification of recombinant HSP20 proteins}

pAS2-1 plasmids containing wild-type human HSP20 were digested with with EcoRI and Nco I and the product ligated into pET30a+ (Novagen, Gibbstown, NJ) or pTAT-HA bacterial expression vectors. pTAT-HA was a gift of S. Dowdy (University of California, San Diego, CA). In order to generate TAT-HSP20 S16D phosphorylation mimic, Ser ${ }^{16}$ was mutated to aspartate using the QuickChange II sitedirected mutagenesis system (Stratagene, La Jolla, CA). All 
DNA sequences were verified by sequencing at the Nevada Genomics Center, University of Nevada, Reno, Nevada.

Recombinant His(6)-tagged wild type HSP20, TAT-HSP20 and TAT-HSP20 S16D proteins were expressed in Escherichia coli BL21(DE3) pLysS competent cells. His(6)-tagged proteins were extracted by freeze-thaw cycling and solubilization in $8 \mathrm{M}$ urea. His(6)-tagged protein was purified by nickel affinity column chromatography using two $5 \mathrm{~mL}$ HiTrap Chelating HP columns in tandem (GE Healthcare Life Sciences, Uppsala, Sweden). TAT-labeled proteins extracted in $8 \mathrm{M}$ urea were purified using an on-column refolding protocol including a decreasing gradient of 8 to $0 \mathrm{M}$ urea ( $3 \mathrm{hr}, 1 \mathrm{ml} / \mathrm{min}$ ) followed by protein elution with a 50 to $500 \mathrm{mM}$ imidazole gradient. ${ }^{18}$ NVoy polymer (NV10; Expedeon, Cambridge UK) was added to the eluted protein at $1 \mathrm{mg} / \mathrm{ml}$ to prevent precipitation of TAT-HSP20 and TAT-HSP20 S16D fusion proteins in physiological salt solution. Recombinant TAT-HSP20 preparations were desalted by dialysis against physiological salt solution. Protein purity was greater than $90 \%$ as determined by SDS-PAGE, staining with Bio-Safe Coomassie stain (BioRad) and densitometry after fluorescence imaging with a LI-COR Odyssey scanner. The recombinant protein was immunoreactive with anti-HSP20 antibodies on Western blots.

\section{Actin-myosin-binding assay}

Binding of gizzard myosin S1 fragment to the rabbit skeletal muscle actin-tropomyosin complex was assayed by sedimentation. Smooth muscle myosin was prepared from frozen chicken gizzards. ${ }^{19}$ The head fragment, S1, was prepared from a Staphylococcus aureus protease V8 digestion of smooth muscle myosin with modifications..$^{20,21}$ Gizzard tropomyosin was prepared from chicken gizzards. ${ }^{22} \mathrm{~F}$-actin was prepared from rabbit skeletal muscle. ${ }^{23}$ Protein concentrations were determined using the following molar extinction coefficients (280 nm): smooth muscle myosin, 0.56; HMM, 0.65 and myosin S1, 0.75. Binding of gizzard myosin S1 fragment to rabbit skeletal muscle actin was assayed by sedimentation. Recombinant human HSP20 was phosphorylated with recombinant protein kinase A (PKA) by combining $400 \mu \mathrm{g}$ HSP2 0 in $500 \mu \mathrm{l}$ total volume with $50 \mu 1$ of $10 \mathrm{X}$ PKA kinase buffer containing $500 \mathrm{mM}$ Tris $\mathrm{pH} 7.2,100 \mathrm{mM} \mathrm{MgCl}_{2}$ and $10 \mathrm{mM}$ DTT, $2 \mathrm{U}$ recombinant PKA catalytic subunit (C8482; Sigma Chemical Co., St. Louis, MO), and $50 \mu \mathrm{l}$ of $1 \mathrm{mM}$ ATP. The reaction was incubated at $30{ }^{\circ} \mathrm{C}$ for one hour and phosphorylation was verified by nondenaturing gel electrophoresis and western blotting using anti-phosphoSer ${ }^{16}$ antibodies. Gizzard tropomyosin and HSP20 proteins were dialyzed vs $\mathrm{S} 1$ buffer (0.3 M NaCl, $30 \mathrm{mM}$ MOPS, pH 7.0, $0.5 \mathrm{mM}$ DTT, $0.2 \mathrm{mM}$ EGTA). Purified rabbit skeletal actin (5 $\mu \mathrm{M})$, chicken gizzard tropomyosin $(1.4 \mu \mathrm{M})$, chicken gizzard myosin S1 fragment $(2.5 \mu \mathrm{M})$ and ADP $(50 \mu \mathrm{M})$ were incubated at $10^{\circ} \mathrm{C}$ for $20 \mathrm{~min}$ in the presence of one of the following treatments: $\mathrm{S} 1$ buffer only, $1 \mathrm{mM}$ sodium orthovanadate, $5 \mu \mathrm{M}$ HSP20, or $5 \mu \mathrm{M}$ phosphorylated HSP20. The binding reaction was carried out in a Beckman Coulter TLA120 rotor (Beckman Coulter, Inc., Fullerton, $\mathrm{CA}$ ) at $10{ }^{\circ} \mathrm{C}$ for $20 \mathrm{~min}$. Bound and free $\mathrm{S} 1$ were separated by sedimentation of actin filaments at 200,000 $\times \mathrm{g}, 20 \mathrm{~min}$, $10{ }^{\circ} \mathrm{C}$. Actin and myosin S1 contents of the supernatant and pellet were determined by SDS-PAGE, staining with BioSafe Coommassie (BioRad) and densitometry using an Odyssey scanner and software (LI-COR Biosciences).

\section{Actin sliding velocity assay}

Velocity of tetramethylrhodamine isothiocyanate (TRITC) phalloidin labeled rabbit skeletal muscle actin was assayed according to Hooft and colleagues. ${ }^{24}$ Flow cells for the motility assay were prepared as follows: $2 \times 40 \mu \mathrm{l}$ washes of $100 \mu \mathrm{g} / \mathrm{ml}$ myosin with a $1 \mathrm{~min}$ incubation period, $2 \times 40 \mu \mathrm{l}$ washes with $0.5 \mathrm{mg} / \mathrm{ml}$ BSA, $2 \times 40 \mu \mathrm{l}$ washes of $10 \mathrm{mM}$ actin with a $1 \mathrm{~min}$ incubation period, $2 \times 40 \mu \mathrm{l}$ washes with actin buffer, and $2 \times 40 \mu \mathrm{l}$ washes with motility buffer. Motility assays were performed using a Nikon TE2000 epifluorescence microscope with fluorescent images digitally acquired with a Roper Cascade 512B camera (Princeton Instruments, Trenton, NJ). The velocities of the moving actin filaments were plotted as a histogram and fitted to a Gaussian distribution. The average velocity, $V$, for the field was taken from the mean of the Gaussian fit. Velocities obtained from the Gaussian distributions of the three image fields per flow cell were used to calculate an average velocity for the flow cell. These experiments were repeated four times for each condition.

\section{HSP20 macromolecular complexes analyzed by gel filtration chromatography}

Strips of tracheal smooth muscle $(50 \mathrm{mg})$ from seven dogs were mounted isometrically on stainless steel hooks and stretched to remove any slack from the tissue. The preloaded strips were incubated $30 \mathrm{~min}$ in oxygenated PSS in a tissue bath at $37^{\circ} \mathrm{C}$. Tissues were stimulated three times for $5 \mathrm{~min}$ with $1 \mu \mathrm{M}$ carbachol. One strip from each group was attached to a force transducer to measure contraction. This strip served as unstimulated control after $30 \mathrm{~min}$ in PSS following carbachol and isoproterenol treatments. All strips were stimulated 15 min with $1 \mu \mathrm{M}$ carbachol then one was treated an addi- 
tional 10 min with $10 \mu \mathrm{M}$ isoproterenol to induce relaxation. Soluble proteins were isolated by homogenization using glass Kontes \#22 homogenizers in ice-cold gel filtration buffer plus protease inhibitors. Gel filtration buffer was composed of: $25 \mathrm{mM}$ HEPES (pH 7, $22{ }^{\circ} \mathrm{C}$ ), $150 \mathrm{mM} \mathrm{NaCl}, 1 \mathrm{mM}$ $\mathrm{Na}_{2}$ EDTA, $1 \mathrm{mM}$ DTT. The homogenates were clarified by centrifugation at $100,000 \mathrm{~g}, 30 \mathrm{~min}, 4^{\circ} \mathrm{C}$. Protein complexes in the $100,000 \times \mathrm{g}$ supernatant were then separated by gel filtration chromatography using a Superose 12 10/300 GL column (Amersham Biosciences, Fairfield, CT) developed at $0.5 \mathrm{ml} / \mathrm{min}$ flow rate. Molecular mass of macromolecular complexes was determined by calibrating the column with purified globular protein standards (MWF-GF-1000; Sigma Chemical Co.). Samples of column fractions eluting between 13-42 min were assayed for HSP20 content by immunoblotting with anti-HSP20 antibodies. Recombinant HSP20 (5-100 ng) was included on the blots to generate a standard curve for quantitation of protein content of each fraction.

\section{Statistical methods}

Statistical hypothesis testing was performed by one-way analysis of variance (ANOVA) followed by post-hoc testing. Dunnett's test was used to compare all treatments to a defined control group. A paired $t$-test was used in studies where repeated measures were made on the same subject (tissue strip). Statistical calculations were accomplished using GraphPad Prism software (version 4.00 for Windows; GraphPad Software, San Diego, CA). When P $<0.05$, the null hypothesis was rejected.

\section{Materials}

Peptides were synthesized by Biopeptide Co. (San Diego, CA) and by the Proteomics Core Lab (University of Nevada, Reno, NV). Sodium arsenite $\left(\mathrm{NaAsO}_{2}\right), \mathrm{TNF} \alpha$, IL- $1 \beta$, IFN $\gamma$, isoproterenol, salmeterol and cell culture reagents were purchased from Sigma Chemical Co. Alexa-680 and IR-Dye labeled secondary antibodies (Cat. No. 926-32221, 92632220, 926-32210, 926-32211) were obtained from LI-COR Biosciences. Hydrogen peroxide $\left(\mathrm{H}_{2} \mathrm{O}_{2}\right)$ was purchased from Fischer Scientific (Houston, TX). Phalloidin Texas Red-X was purchased from Molecular Probes (Eugene, OR). Cell culture media were purchased from Invitrogen.

\section{Results}

\section{Modulation of HSP20 expression in airway smooth muscle}

Several small heat shock proteins including alpha $B$ crystallin (HSPB5), HSP27 (HSPB1), and HSP20 (HSPB6) are constitutively expressed in vascular smooth muscle. ${ }^{2,25}$ HSP20 is expressed at varying levels in vascular, urinary bladder, and uterine smooth muscle depending on the vascular bed, the presence of flow obstruction, and pregnancy status, respectively. ${ }^{11,12,25}$ Several studies showed cyclic nucleotide-induced relaxation of smooth muscle depends in part on the level of HSP20 expression and requires phosphorylation of HSP20. ${ }^{10,11}$ Because proinflammatory agents including TNF $\alpha$, IL- $1 \beta$, and IFN $\gamma$ are known to enhance contraction or antagonize relaxation of airway smooth muscle, ${ }^{13,14}$ we tested for variability in HSP20 expression as a contributor to altered airway reactivity. HSP20 expression was assayed by Western blotting of proteins extracted with SDS from cultured hASM cells. All expression data were generated by loading equal amounts of protein and using COX-1 as a loading control. ${ }^{26}$ Expression of each protein was normalized to its level of expression at 0 hours. No significant changes in COX-1 expression were observed in response to any treatments confirming the validity of this constitutively expressed enzyme as a reference control (dashed lines in Figure 1). We found the combination of TNF $\alpha$, IL $\beta$, and IFN $\gamma$ significantly inhibited expreression of HSP20 after 48 hours (Figure 1A).

Expression of small heat shock proteins can be induced in some cell types in response to oxidative and metabolic stressors that regulate polymerization of heat shock factors HSF1, HSF2 and HSF4 that in turn enhance trancription of small heat shock proteins. ${ }^{27}$ To determine if oxidative or metabolic stress could upregulated HSP20 in hASM cells we treated cells in culture with $1 \mu \mathrm{M}$ hydrogen peroxide, an oxidative stressor, or $20 \mu \mathrm{M}$ sodium arsenite, a metabolic toxin. Neither treatement consistently altered HSP20 expression (data not shown).

Chronic activation of cardiac $\beta 1$-adrenergic receptors increases HSP20 expression in the failing heart. ${ }^{28}$ Since $\beta$-adrenergic agonists are used for both acute and chronic treatement of asthma we tested the effects of a short acting (isoproterenol) and a long acting (salmeterol) $\beta$-agonist on expression of HSP20. Cultured hASM cells treated for 24 and 48 hours with $\beta$ agonists showed significant upregulation of HSP2 0 by 2.5 -fold at 48 hours (Figure $1 \mathrm{~B}$ and $1 \mathrm{C}$ ). The results demonstrate HSP20 is constitutively expressed in airway smooth muscle, but expression in vitro is variable under conditions that mimic airway inflammation and treatment of airways obstruction with $\beta$-adrenergic agonists.

\section{Phosphorylation of HSP20 in airway smooth muscle}

Phosphorylation of HSP20 is hypothesized to be sufficient to induce smooth muscle relaxation. ${ }^{4,6}$ HSP20 is 
phosphorylated in intact smooth muscle at $\operatorname{Ser}^{16}$, which is within a cyclic nucleotide-dependent protein kinase (PKA) consensus phosphorylation motif (WLRRASAPLPGLS). ${ }^{2}$ To verify that this phosphorylation event occurs in human airway smooth muscle, hASM cells were stimulated with forskolin to activate adenylate cyclase and PKA. We assayed cAMP-dependent HSP20 phosphorylation by immunoblotting using an anti-phospho $\mathrm{Ser}^{16}$ selective antibody. ${ }^{2}$ As shown in Figure 2A, HSP20 phosphorylation could be induced in hASM cells treated with forskolin (1 or $10 \mu \mathrm{M})$. In addition we showed HSP20 is phosphorylated at Ser $^{16}$ in strips of canine tracheal smooth muscle tissue (Figure 2B).

\section{Cell permeant HSP20 phosphopeptide antagonizes contraction of canine airway smooth muscle}

We next determined whether phosphorylation of HSP20 is sufficient to induce relaxation of canine tracheal smooth muscle tissue. Komalavilas and colleagues showed previously that a cell permeant peptide containing the PKA phosphorylation site in HSP20 could be delivered to intact bovine tracheal smooth muscle tissues to cause relaxation. ${ }^{8}$ The peptide sequence (YARAAARQARAWLRRAS( $\mathrm{PO}_{3}$ )A PLPGLK) includes a protein transduction motif at residues 1-11 and 12 residues flanking Ser ${ }^{16}$ of human HSP20. We tested the same peptide in canine airway smooth muscle contracted with $0.1 \mu \mathrm{M}$ carbachol. Muscle strips were stimulated once with $0.1 \mu \mathrm{M}$ carbachol prior to incubation with the phosphopeptide for $20 \mathrm{~min}$. After a $10 \mathrm{~min}$ wash, a second response to carbachol was elicited and found to be reduced to $40 \%$ of control (Figure $3 \mathrm{~A}$ ). A control peptide with the same protein transduction motif, but a scrambled sequence surrounding the phosphoserine (YA RAAARQARAPRKS(PO ${ }_{3}$ LWALGRPLA) did not affect contraction (Figure 3B). To verify that the cell-permeant HSP20 phosphopeptide permeated the entire muscle a carboxyfluorescein-labeled phosphopeptide was synthesized and incubated with canine tracheal smooth muscle strips for $20 \mathrm{~min}$. The strips were washed $10 \mathrm{~min}$ as in the contractile studies, embedded in optimum cutting temperature medium (OCT) and cryosections cut for fluorescence microscopy. Fluorescence micrographs of longitudinal
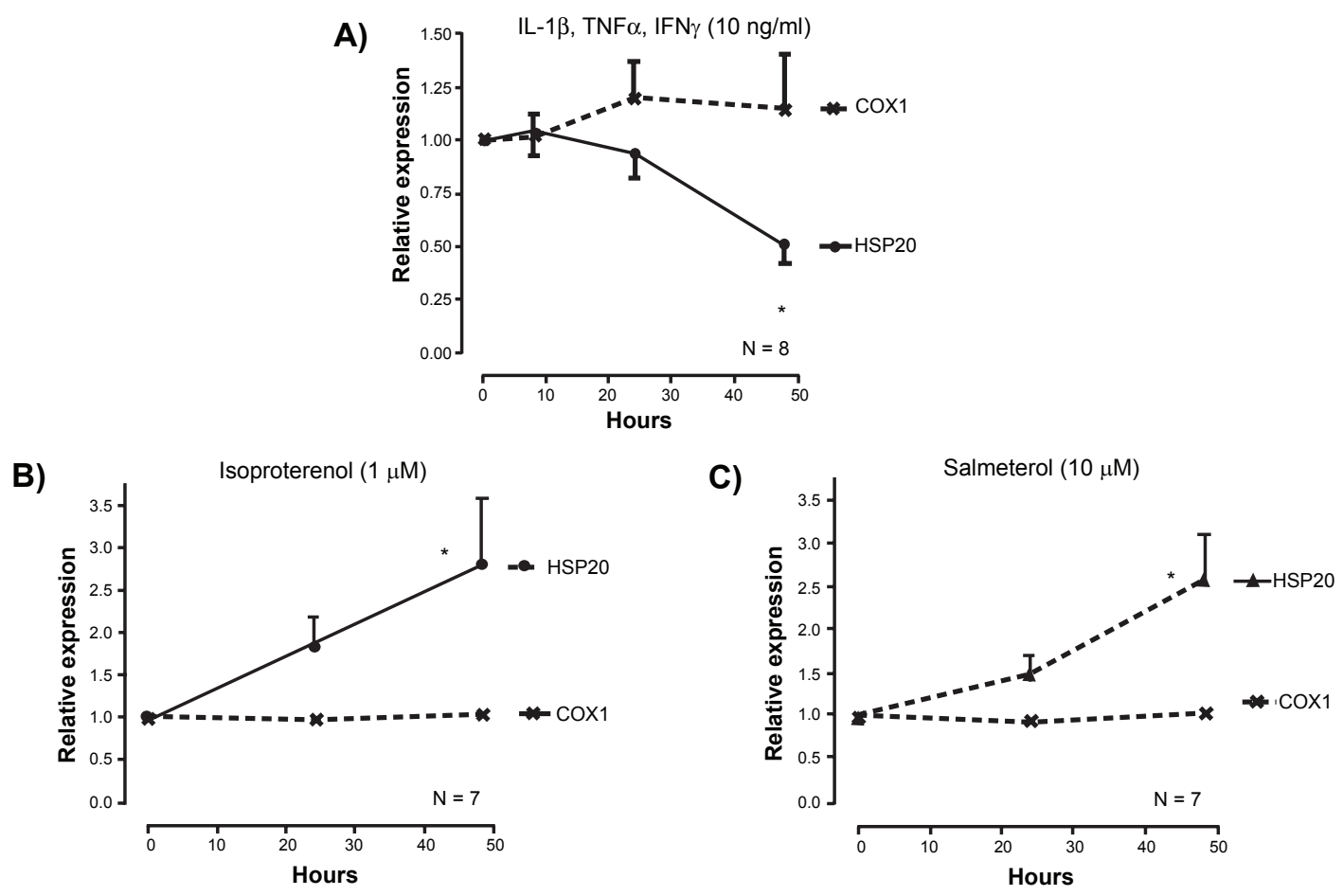

Figure I Modulation of HSP20 expression in hASM cells. Low passage (4-9) hASM cells were stimulated for the times indicated with one of the following treatments: $20 \mathrm{mg} / \mathrm{ml} \mathrm{TNF} \alpha$ alone, a cytokine mixture ( $10 \mathrm{ng} / \mathrm{ml}$ each, IL- I $\beta$, TNF $\alpha$, IFN $\gamma)$, I $\mu$ M isoproterenol or $10 \mu$ M salmeterol. HSP20 expression was assayed by immunoblotting and protein levels normalized to expression in unstimulated cells ( 0 hours). COX-I expression was assayed on the same blots, and protein levels normalized to expression in unstimulated cells ( 0 hours).

Notes: ${ }^{*} \mathrm{P}<0.05$ compared to 0 hour sample; Dunnet's test.

Abbreviations: COX-I, cycloxygenase-I; IFN, interferon; IL, interleukin;TNF $\alpha$, tumor necrosis factor alpha. 
A) hASMC

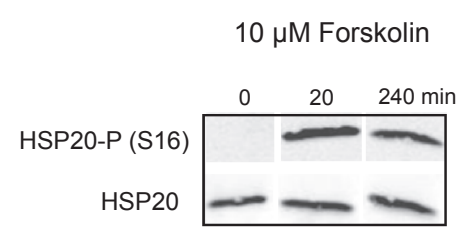

\section{B) Canine trachea}

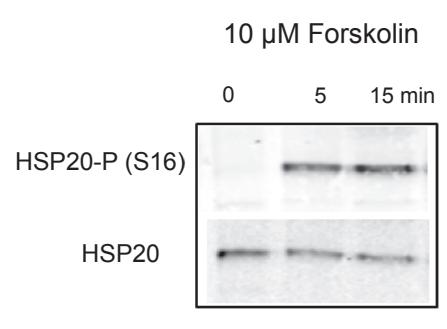

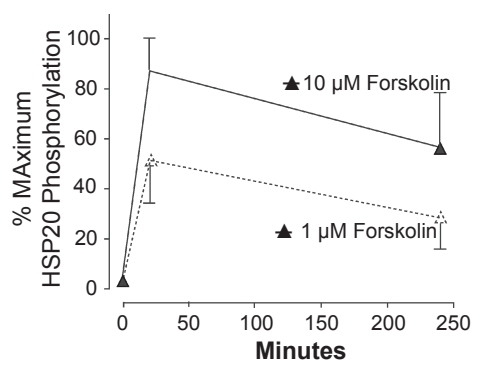

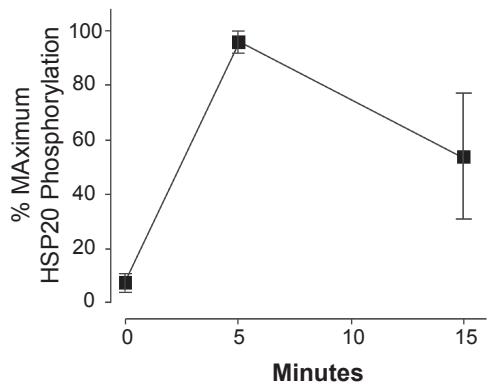

Figure 2 Forskolin stimulates phosphorylation of HSP20 in hASM cells and canine tracheal smooth muscle tissue. A) Cultured hASM cells stimulated with I or $10 \mu$ M forskolin for 20 and 240 min were assayed for HSP20 and phosphorylated HSP20 expression by immunoblotting. Relative phosphorylation was calculated by normalizing phosphor-HSP20 immunoreactivity to the levels at 20 min stimulation. $\mathrm{N}=4$. B) Canine tracheal strips were incubated with I0 $\mu$ M forskolin for 5 or I5 min, frozen in cold acetone $/ 5 \%$ trichloroacetic acid and homogenized. HSP2O and phosphorylated HSP20 were assayed by immunoblotting, and relative phosphorylation calculated by normalizing to the levels at 5 min stimulation. $\mathrm{N}=4$.

sections and cross-sections at higher magnification showed the peptide permeated throughout the muscle preparation and into the cells (Figure 4). Collectively, the results confirm previous studies of HSP20 phosphorylation and smooth muscle relaxation, ${ }^{6,8}$ and extend the generality of the relaxant effect of permeant HSP20 phosphopeptide to canine airway smooth muscle.

Inhibition of hASM contraction by the HSP20 phosphopeptide could be due to several established biochemical mechanisms including disruption of the actin
A)

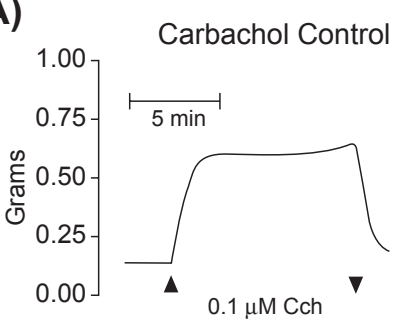

B)

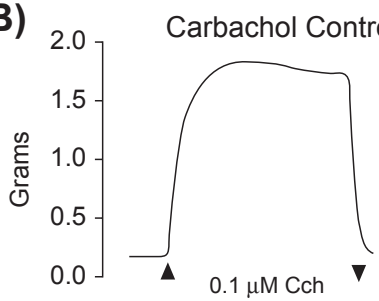

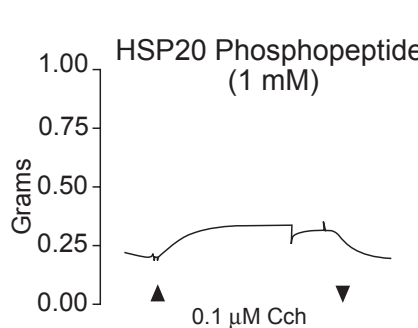

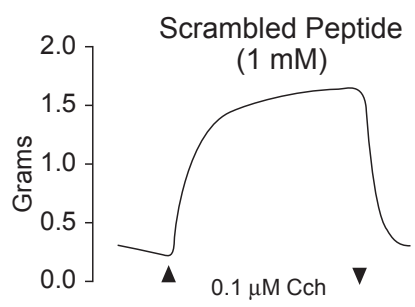

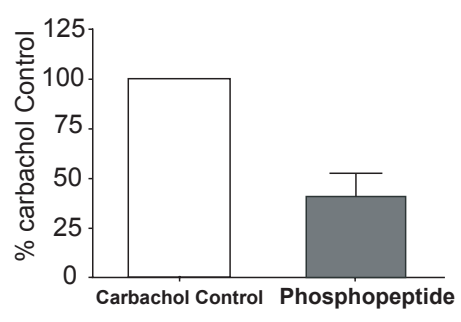

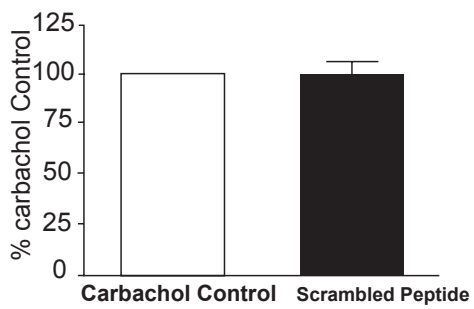

Figure 3 Cell-permeant HSP20 phosphopeptide inhibits contraction. A) Strips of canine tracheal smooth muscle were stimulated twice with $0.1 \mu$ M carbachol - once before (Control) and once after 20 min incubation with I mM HSP20 phosphopeptide mimic containing a protein transduction motif. The grey bar shows a significant decrease in force in the presence of the phosphopeptide mimic. B) A series of two contractions were elicited before (Control) and after 20 min incubation with a phosphopeptide of identical amino acid composition but scrambled sequence. The black bar indicates no change in mean force elicited by carbachol; $N=6$.

Notes: ${ }^{*} \mathrm{P}<0.05, \mathrm{~N}=6$, paired $t$-test. 

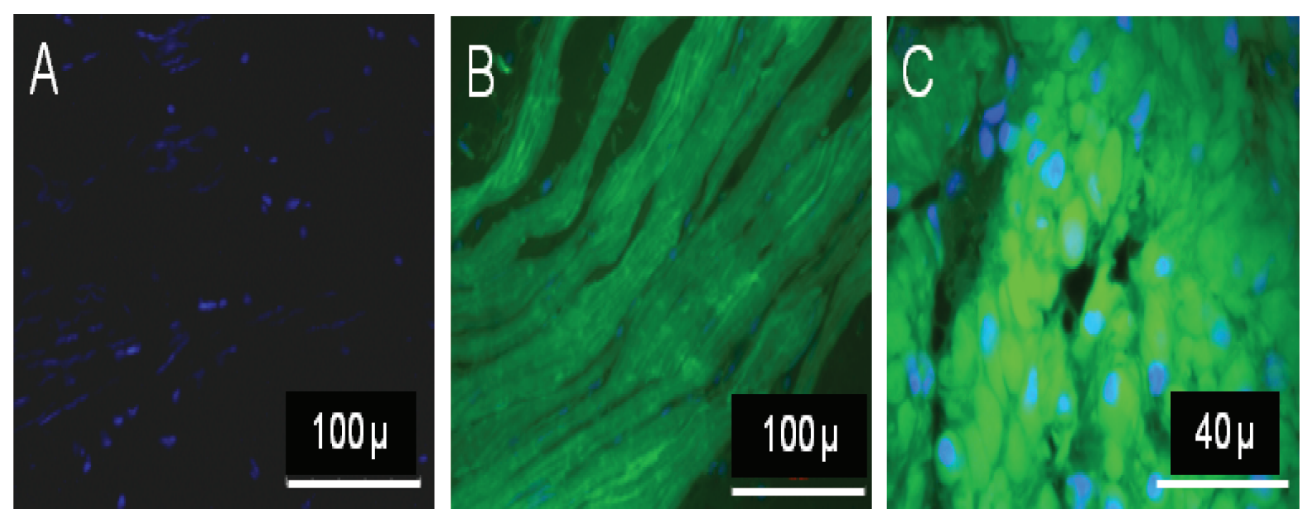

Figure 4 HSP20 phosphopeptide permeates canine tracheal smooth muscle. A) Background fluorescence of canine tracheal smooth muscle strips. Tissues were counterstained with DAPI and washed in PSS 10 min prior to freezing and embedding for longitudinal sectioning and imaging. B) Fluorescence of a cryosection of tracheal smooth muscle strip incubated 20 min with I mM fluorescein-modified cell permeant HSP20 phosphopeptide. C) Higher power cross-section of a tracheal strip showing uptake of the fluorescent peptide throughout the cells. Similar results were obtained in tracheal tissues from three different animals.

cytoskeleton, ${ }^{8}$ suppression of force by inhibition of actomyosin crossbridges, ${ }^{29,30}$ or inhibiting excitationcontraction coupling. ${ }^{31,32}$ To test for inhibition of excitation mechanisms we assayed myosin light chain phosphorylation because it is the final calcium-dependent biochemical step in excitation-contraction coupling in smooth muscle, and is necessary for force development. Three sets of canine tracheal smooth muscle strips were incubated 20 min with PSS, $1 \mathrm{mM}$ HSP20 phosphopeptide, or $1 \mathrm{mM}$ scrambled control peptide. Muscle strips were then incubated with carbachol for 0,1 , or $5 \mathrm{~min}$, frozen and assayed for myosin light chain phosphorylation by nondenaturing PAGE and immunoblotting with anti-myosin light chain antibody. Figure 5 shows neither the HSP20 phosphopeptide nor the scrambled control peptide inhibited myosin light chain phosphorylation, suggesting muscarinic activation of calcium-dependent signaling to the contractile apparatus was unaffected.

\section{Effect of HSP20 on SI myosin binding to actin}

Other mechanisms by which phosphorylated HSP20 might inhibit contraction include reducing actomyosin ATPase activity or reducing actin binding to myosin. ${ }^{29,30}$ We tested both hypotheses by measuring actin sliding velocity in an in vitro motility assay and by measuring gizzard myosin $\mathrm{S} 1$ binding to actin-tropomyosin using a sedimentation assay. We did not observe any inhibitory effect of $5 \mu \mathrm{M}$ HSP2 0 or $5 \mu \mathrm{M}$ phosphorylated HSP2 0 on mean actin sliding velocity using rabbit skeletal myosin. In fact, velocity increased slightly (Figure 6). This suggests there is no inhibitory effect of HSP20 on the

\section{Control}

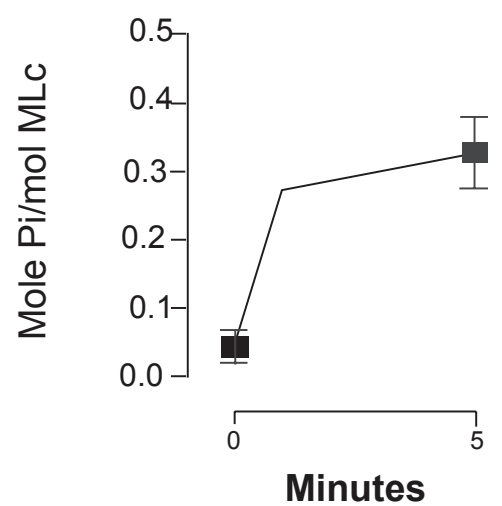

HSP20 phosphopeptide

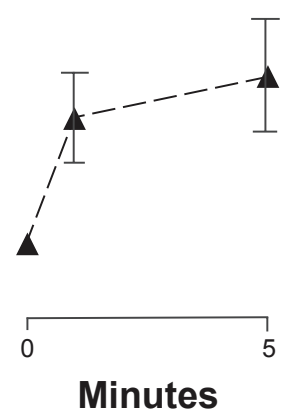

\section{Scambled peptide}

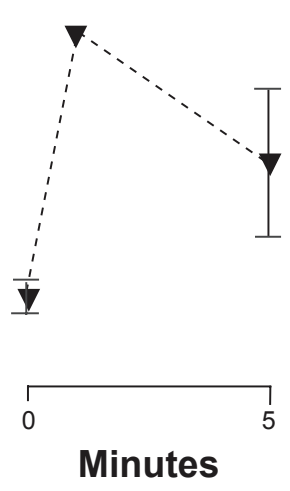

Figure 5 HSP20 phosphopeptide does not inhibit myosin light chain phosphorylation. Canine tracheal strips were stimulated with $0.1 \mu$ M carbachol for 0 or 5 min, frozen in acetone $/ 5 \%$ trichloroacetic acid $\left(-80^{\circ} \mathrm{C}\right)$ and myosin light chains extracted by incubation of the strips in $8 \mathrm{M}$ urea. Phosphorylated and unphosphorylated $20 \mathrm{kDa}$ myosin light chains were resolved by nondenaturing PAGE and phosphorylation stoichiometry calculated from densitometry of immunoblots. $\mathrm{N}=4$. 
kinetics of sliding actin filaments. However, due to the nature of this assay, which measures only moving filaments, it does not detect less than $100 \%$ inhibition of the initial actin-myosin binding step. Nonmoving filaments are disregarded during data analysis. Thus it was necessary to test for inhibition of myosin binding to actin-tropomyosin more directly.

Rabbit skeletal muscle actin filaments decorated with chicken gizzard tropomyosin were incubated with gizzard myosin S1 fragments in the presence of $50 \mu \mathrm{M}$ ADP to trap the crossbridge in a strongly attached state. Both rabbit skeletal myosin S1 (not shown) and chicken gizzard myosin S1 were tested (Figure 7). Bound and free myosin S1 was separated by sedimentation and protein content of the supernatant and pellet assayed by SDS-PAGE and densitometry of commassie-blue stained proteins. More than $80 \%$ of myosin $\mathrm{S} 1$ was bound to actin-tropomyosin in the presence of $50 \mu \mathrm{M} \mathrm{Na} \mathrm{ADP}_{2} \mathrm{ADP}$ (Figure 7; control). As a positive control we showed that $\mathrm{S} 1$ binding was antagonized by $1 \mathrm{mM}$ sodium orthovanadate, which is a phosphate analog that reduces the strong binding of actin and myosin (Figure 7; vanadate). We then tested the effect of $5 \mu \mathrm{M}$ HSP2 0 or $5 \mu \mathrm{M}$ phosphorylated HSP20 and found S1 binding reduced significantly to $50 \%$ bound compared to control (Figure 7). The results suggest HSP20 is able to interact with actin and myosin in solution and to weaken myosin S1 binding to actin, which should promote relaxation of intact muscle. The inhibition of

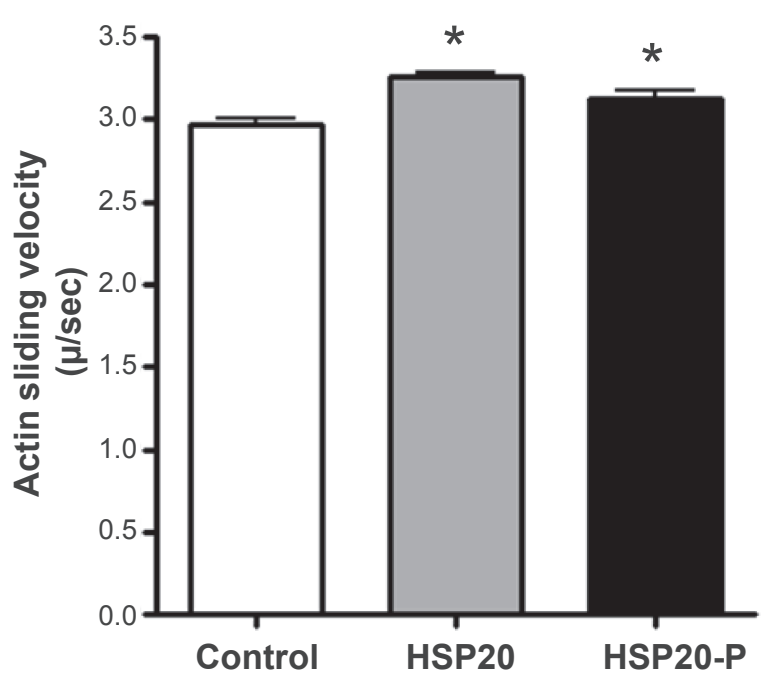

Figure 6 HSP20 does not inhibit actin sliding velocity. Sliding velocity of tetramethylrhodamine isothiocyanate (TRITC) phalloidin labeled rabbit skeletal muscle actin was assayed in flow cells containing $100 \mu \mathrm{g} / \mathrm{ml}$ rabbit skeletal myosin. Recombinant human HSP2O was phosphorylated to I mole $\mathrm{Pi} /$ mole protein with purified protein kinase A. Actin motility was visualized by fluorescence videomicroscopy and velocities were fitted to a Gaussian distribution from which the average velocity for each field was calculated. Velocities of nine different fields in four flow cells per condition were averaged.

Notes: *P $<0.05$ compared to control; Dunnet's test.
S1 binding appeared to be independent of phosphorylation of HSP20 (Figure 7; HSP20-P). This result is consistent with a model where phosphorylation may regulate the availability of HSP20 to interact with actin and myosin, but inhibition of crossbridge formation and contraction may be due to a different molecular mechanism, possibly the presence of a TnI motif in HSP20. ${ }^{29}$ This hypothesis remains to be tested directly, but the data are most consistent with both phosphorylated and nonphosphorylated HSP20 weakening the binding of myosin to actin-tropomyosin.

\section{Disruption of actin filaments by full-length TAT-HSP20 phosphomimetic} To determine whether HSP20 can alter F-actin filament structure we synthesized recombinant cell-permeant full length HSP2 0 proteins. Both wild type and $\operatorname{Ser}^{16}$ to Asp mutant proteins were expressed in E. coli, purified and incubated with cultured hASM cells. F-actin in fixed cells was then stained with phalloidin-Texas Red $X$. This approach has the advantage of including all the functional motifs of the native HSP20 including the PKA phosphorylation site, the alpha crystallin domain and the troponin I-like motif. The TAT-HSP20 S16D phosphomimetic protein produced profound and consistent disruption of F-actin (Figure 8C) that was similar to the effect of $10 \mu \mathrm{M}$ cytochalasin D (Figure 8B). Wild-type unphosphorylated HSP20 had no effect on F-actin filaments (Figure 8D).

\section{Inhibition of hASM contraction}

\section{by TAT-HSP20 SI6D cell permeant protein}

To determine whether the TAT-HSP20 proteins could alter tracheal smooth muscle contraction, porcine tracheal smooth muscle strips were mounted in an isometric muscle bath and incubated with either TAT-HSP20 wild-type (9A) or TATHSP20 S16D (Figure 9B). Three cumulative methacholine concentration response curves were constructed in series. The first two curves were control responses that did not differ in maximum stress or half maximal effective concentration $\left(\mathrm{EC}_{50}\right)$. Between the second and third concentration-response tissues were treated $90 \mathrm{~min}$ in PSS plus $2.5 \mu \mathrm{M}$ wild type or S16D HSP20 protein. As shown in Figure 9 TAT-HSP20 S16D phosphomimetic inhibited contraction by $20 \%$ with no significant effect on methacholine sensitivity $\left(\mathrm{EC}_{50}\right)$.

\section{Subcellular distribution \\ and macromolecular complexes}

To more fully understand the mechanism of relaxation by HSP20 we wanted to establish the subcellular location of the protein. One approach was to homogenize canine tracheal 


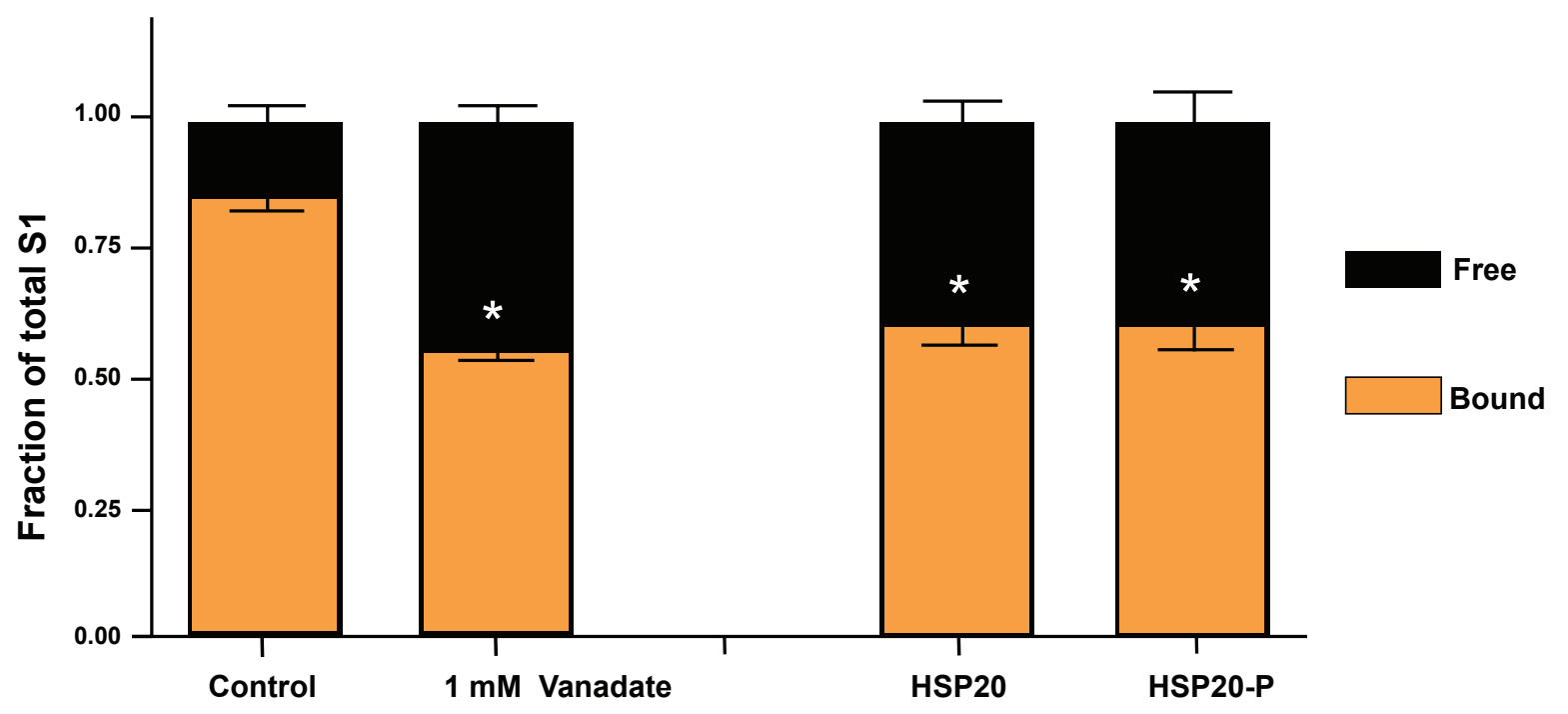

Figure 7 HSP20 reduces binding of myosin SI to actin-tropomyosin. Rabbit skeletal F-actin was bound with gizzard tropomyosin at a I:7 molar ratio prior to binding to gizzard myosin SI for $20 \mathrm{~min}$ at $10^{\circ} \mathrm{C}$ in the presence of $50 \mu \mathrm{MADP}$. Binding was conducted in the presence of one of the following treatments: I mM sodium orthovanadate, $5 \mu \mathrm{M}$ recombinant human $\mathrm{HSP} 20$ or $5 \mu \mathrm{M} \mathrm{HSP} 20$ phosphorylated by PKA (HSP20-P). Free and bound SI were separated by centrifugation of actin-SI complexes at $200,000 \mathrm{~g}$, $10{ }^{\circ} \mathrm{C}$, $10 \mathrm{~min}$. Free $\mathrm{SI}$ in the supernatant and bound $\mathrm{SI}$ in the pellet were assayed by SDS-PAGE and commassie blue staining followed by fluorescence imaging with a LI-COR Odyssey laser scanner $(\mathrm{Em}-680 \mathrm{~nm}) . \mathrm{N}=4$ assays conducted in duplicate.

Notes: *P $<0.05$ compared to control group; Dunnet's test.

tissue in ice-cold gel filtration chromatography buffer followed by pelleting membranes, organelles, and cytoskeletal proteins at $100,000 \times \mathrm{g}$. Proteins in the supernatants and pellets were resolved by SDS PAGE. Western blotting was used to define the fraction of total HSP20 muscle that is membrane associated (pellet) vs cytosolic (supernatant) (Figure 10A). Results from fractionation studies in Figure 10A show that most HSP20 was extracted into the cytosolic fraction (S), and that stimulation with carbachol or isoproterenol did not cause the protein to redistribute significantly to the particulate fraction $(\mathrm{P})$.

To define the extent to which HSP20 is distributed to Triton-soluble vs insoluble (cytoskeletal) pools we fixed cultured hASM cells in 4\% paraformaldehyde before and after washing cells with $0.1 \%$ Triton-X 100 . HSP20 was detected with anti-HSP20 antibodies (Figure 10B). The goal of this experiment was to define the Triton-resistant pool of protein, which is commonly interpreted as being proteins avidly bound to the cytoskeleton. The issue we wanted to address was whether HSP20 was a stable component of the contractile apparatus and the actin cytoskeleton, or whether it was readily dissociable. Several previous studies suggested HSP20 is an actin binding protein, possibly bound to contractile and/or actin cytoskeletal filaments. ${ }^{33}$ However, direct biochemical assays of HSP20 biding to actin and artificial thin filaments challenged this notion. ${ }^{34}$ In our experiments staining of HSP20 was observed throughout the cell with some areas of filamentous staining (Figure 10A). Forskolin treatment did not produce dramatic redistribution of HSP20 (Figure 10B), although perinuclear staining was enhanced somewhat and peripheral staining was reduced. In contrast, in cells washed with $0.1 \%$ Triton-X 100 little HSP20 was retained (Figure 10C). These results suggest HSP20 is not tightly associated with the cytoskeleton in hASM cells in culture or in canine tracheal muscle.

HSP20 forms macromolecular aggregates in cells that range from about 40 to $500 \mathrm{kDa} \cdot{ }^{35,36} \mathrm{Gel}$ filtration chromatography has been used to assess macromolecular complexes of small heat shock proteins in several cell types. ${ }^{37-39}$ To determine whether macromolecular complexes containing HSP20 are dynamic in hASM during contraction and relaxation we assayed cytosolic HSP20 protein complexes in carbachol-stimulated tissues and in contracting tissues treated with isoproterenol. Soluble protein complexes were isolated from canine tracheal smooth muscle under the same nondenaturing conditions as in Figure 10A. HSP20containing complexes separated by gel filtration chromatography were found to distribute into two major peaks of very large $(500-700 \mathrm{kDa})$ complexes and much smaller complexes $<60 \mathrm{kDa}$ (Figure 11). Carbachol stimulation significantly shifted HSP20 immunoreactive fractions from the 500-700 kDa complexes to smaller complexes $<60 \mathrm{kDa}$. Interestingly adding isoproterenol after a $20 \mathrm{~min}$ carbachol 

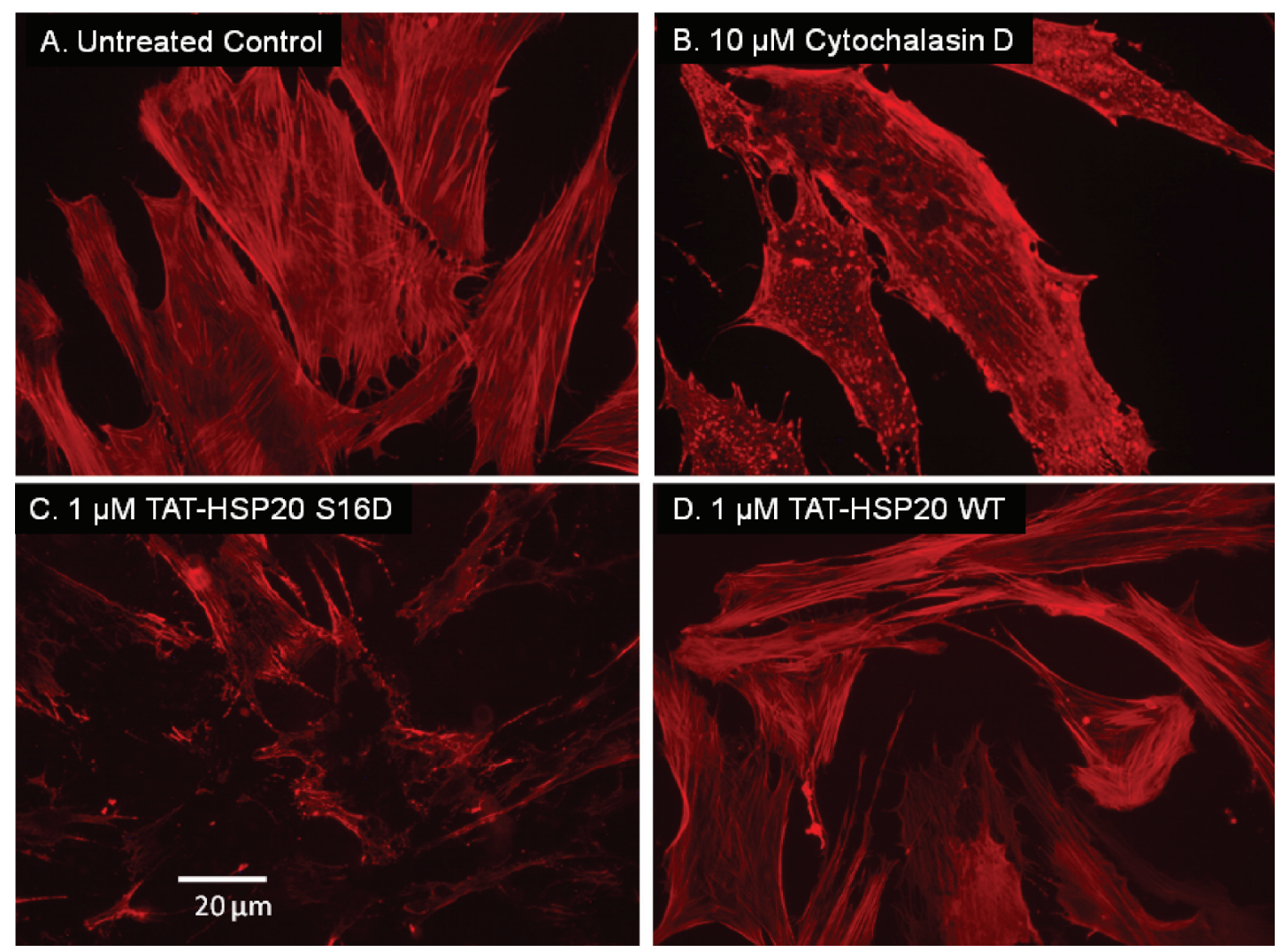

Figure 8 HSP20 phosphorylation mimetic disrupts F-actin. A) Growth-arrested hASM cells were fixed and stained with phalloidin-Texas Red X to visualize F-actin filaments. B) Cells incubated $2 \mathrm{hr}$ with $10 \mu \mathrm{M}$ cytochalasin D to disrupt F-actin. C) Cells incubated for two hours with I $\mu$ M TAT-HSP20 phosphomimetic (SI6D) full length protein showed little filamentous actin staining. D) One $\mu$ M TAT-HSP20 wild type (WT) full length protein had no effect on F-actin filaments. Representative images are from one experiment performed on cells from five different human donors.

Abbreviation: hASM, human airway smooth muscle.

\section{A) TAT-HSP20 wild type}

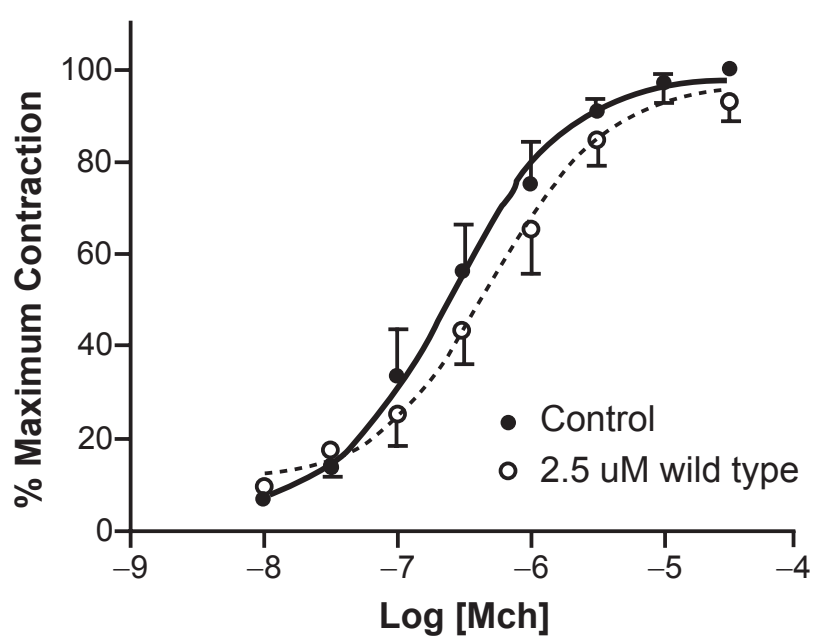

B) TAT-HSP20 S16D

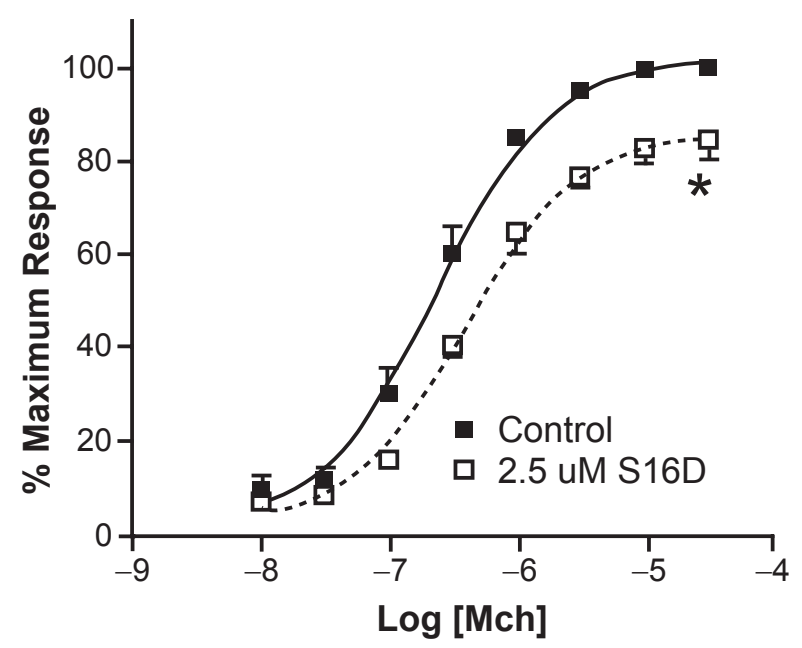

Figure 9 HSP20 phosphomimetic protein antagonizes contraction. Two methacholine concentration response curves were constructed using porcine tracheal smooth muscle strips. A control curve was constructed first followed by 90 min incubation in either $2.5 \mu$ M TAT-HSP20 wild type full length protein (panel A) or $2.5 \mu$ M TAT-HSP20 SI6D phosphomimetic full length protein (panel B). The wild type protein had no effect on $\mathrm{EC}_{50}$ or maximum force elicited by methacholine. The SI6D phosphomimetic had no significant effect on $\mathrm{EC}_{50}$ but reduced maximum force by $20 \%$.

Notes: $* \mathrm{P}<0.05$, paired $t$-test, $\mathrm{N}=4$.

Abbreviation: $\mathrm{EC}_{50}$, half maximal effective concentration. 
A)

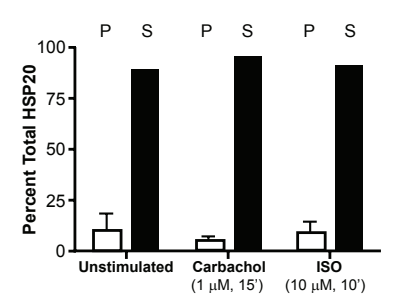

B)
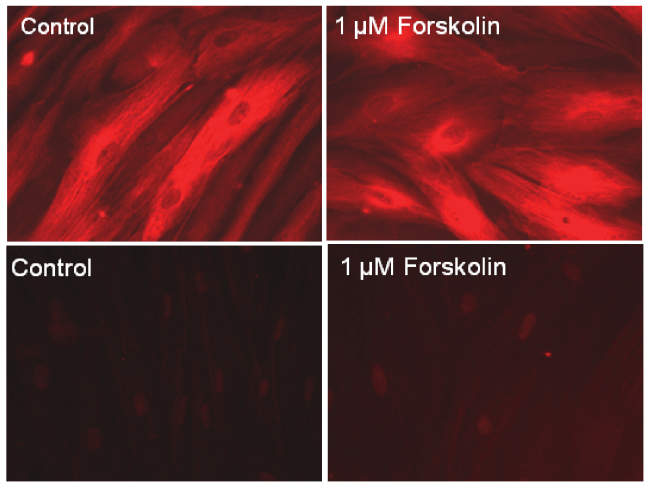

Figure 10 Distribution and cellular location of HSP20. A) Relative distribution of HSP2O in soluble $(S)$ and particulate $(P)$ fractions from canine tracheal smooth muscle homogenates. Muscle strips were homogenized in $25 \mathrm{mM} 25 \mathrm{mM} \mathrm{HEPES}\left(\mathrm{pH} \mathrm{7,22}{ }^{\circ} \mathrm{C}\right)$, $150 \mathrm{mM} \mathrm{NaCl}, \mathrm{I} \mathrm{mM} \mathrm{Na} \mathrm{EDTA}_{2}$ I $\mathrm{mM}$ DTT and the homogenate centrifuged at $100,000 \mathrm{~g}, 30 \mathrm{~min}, 4^{\circ} \mathrm{C}$. HSP20 in the supernatant and pellet fractions was assayed by immunoblotting, $\mathrm{N}=4$. B) HSP20 immunoreactivity in cultured hASM cells treated with I $\mu \mathrm{M}$ forskolin to active adenylate cyclase and phosphorylate HSP20. Cells were fixed with $4 \%$ paraformaldehyde prior to permeabilization with $0.1 \%$ Triton X-100.C) Cells permeabilized with $0.1 \%$ Triton-X 100 prior to fixation with paraformaldehyde and immunocytochemical detection of HSP20. Images shown are typical of experiments on cells from three different human donors.

pretreatment had no further effect on macromolecular size distribution (data not shown). We also probed the fractions for phosphorylated HSP20 and found it distributed through all fractions. Because small heat shock proteins tend to readily form heteropolymers we also probed the fractions for HSP27 (data not shown). There was some overlap in distribution but the general pattern of HSP27 distribution was not identical to the distribution of HSP20. This does not rule out some heteropolymer formation, but it is not consistent with a majority of HSP20 being associated exclusively with HSP27 in airway smooth muscle. The mechanism for the carbachol-induced shift in macromolecular size is unknown. Further it was clear that $\beta$-adrenergic receptor activation was not sufficient to induce a dramatic change in association of HSP20 with its binding partners. Of course subtle protein redistribution in restricted domains of the cell will not be detected by this fairly coarse-grained approach.

\section{Discussion}

HSP20 has been identified as a component of the actin cytoskeleton and the contractile elements in vascular and visceral smooth muscles. Phosphorylation of HSP20 is hypothesized to be necessary for cyclic nucleotide-mediated vasodilation and relaxation of nonvascular smooth muscles. Since many vasodilator and bronchodilator drugs act by increasing cyclic nucleotides it is important to understand how expression of HSP20 is controlled and how the protein might alter force production in smooth muscle. In this study, we investigated the variability of expression of HSP20, the cellular distribution and kinetics of HSP20 macromolecular complexes, and the mechanism by which phosphorylated HSP20 might promote relaxation of airway smooth muscle.

\section{Regulation of expression of HSP20}

In some smooth muscle tissues HSP20 is abundant, but in others it is not and expression levels can vary. Some vascular smooth muscles, bovine airway smooth muscle and uterine smooth muscles express HSP20 constitutively. ${ }^{1,8,12}$ However, the urinary bladder of rabbits is a tissue that does not normally express HSP20 unless the bladder is obstructed, in which case expression increases. ${ }^{11,40}$ Expression of HSP20 is also variable in cerebral vascular smooth muscle and rat myometrium. In rat cerebral arteries, expression is reduced after subarachnoid hemorrhage correlating with impaired vasorelaxation. ${ }^{41}$ In the uterus of pregnant rats HSP20 expression is higher early in gestation and decreases at term. ${ }^{12}$ This is consistent with HSP20 inhibiting contraction and favoring mechanical quiescence early in pregnancy while permitting enhanced contraction near term. The data correlating HSP20 expression and smooth muscle relaxation are consistent with a regulatory model where higher levels of HSP20 expression correlate with effective cyclic nucleotide-mediated relaxation and low or no expression of HSP20 correlates with reduced responsiveness to cyclic nucleotide-induced relaxation.

Because airway smooth muscle in asthmatic airways is probably exposed to multiple autacoids, growth factors, cytokines, NO, and hydrogen peroxide we surveyed treatments that might alter HSP20 expression. The hypothesis was that chemical signals that initiate airway remodeling may do so in part by regulating small heat shock protein expression. Small heat shock proteins are known to regulate multiple cellular processes in smooth muscles including proliferation, cell survival, cell motility, muscle contraction, and actin cytoskeleton dynamics. ${ }^{42,43}$ Surprisingly, oxidative and metabolic stressors including $\mathrm{H}_{2} \mathrm{O}_{2}$ and $\mathrm{NaAsO}_{2}$ had no consistent effect on HSP20 levels. One of the most significant findings of this study was that a mixture of TNF $\alpha$, IL- $\beta$, and IFN $\gamma$, inhibited HSP2 0 expression by $50 \%$ in cultured hASM cells within 48 hours (Figure 1A). The latter observation is consistent with multiple growth factors and proinflammatory 
cytokines in the asthmatic airways acting to suppress HSP20 expression in asthmatics, and possibly impair relaxation. This notion remains to be tested directly in asthmatic humans, but it is consistent with in vitro studies showing cyclic nucleotide-mediated relaxation is reduced in ASM exposed to cytokines and proinflammatory mediators. ${ }^{13}$

Airway smooth muscle of asthmatics are often exposed chronically to both short- and long-acting $\beta$-adrenergic agonists with or without corticosteroids. Because HSP20 expression in the heart is known to be upregulated by chronic $\beta$-adrenergic stimulation during failure, we tested for an effect of isoproterenol and salmeterol to upregulate expression in airway smooth muscle. ${ }^{28}$ Both agents increased HSP20 expression significantly after 48 hours (Figures $1 \mathrm{~B}$ and 1C). The effect of ctyokine mix to reduce expression and $\beta$-agonists to enhance expression suggests a signaling model in which inflammation reduces HSP20 expression thus inhibiting ASM relaxation. Chronic $\beta$-agonist therapy might antagonize inflammatory hyperreactivity in part by upregulating expression of HSP20. Upregulation of HSP20 expression along with acute activation of PKA to phosphorylate HSP20 would favor bronchodilation and improved airway function.

\section{Mechanism of smooth muscle relaxation}

Phosphorylated HSP20 is a dominant inhibitor of smooth muscle contraction, but the molecular mechanism of action is not fully defined. HSP20 is a substrate in vivo for cAMPdependent protein kinase (PKA), which phosphorylates Ser ${ }^{16}{ }^{1,2}$ Binding of phosphorylated HSP20 to the contractile machinery and the actin cytoskeleton is thought to somehow inhibit force production. This was initially demonstrated using a cell-permeant HSP20 phosphopeptide mimic to relax intact vascular smooth muscle. ${ }^{6}$ A similar result was reported using the phosphopeptide mimic to relax bovine tracheal smooth muscle. ${ }^{8}$ This observation is highly relevant to airway physiology in that phosphorylation of HSP20 may be a significant part of the mechanism of action of nitric oxide, $\beta$-adrenergic agonists, and theophylline. It is clear that cAMP inhibits smooth muscle contraction by reducing intracellular calcium levels, thus inhibiting myosin light chain phosphorylation. However, airway and vascular smooth muscle relaxation can also occur without dephosphorylation of myosin light chains. ${ }^{4,44,45}$ These studies suggested there is a biochemical mechanism to inhibit force independent of myosin dephosphorylation, and HSP20 has been proposed as a dominant suppressor of force production in smooth muscles. Two mechanisms have been proposed. One is inhibition of actomyosin crossbridge formation directly by a troponin I-like effect to reduce myosin binding to actin. ${ }^{4}$ Another, nonexclusive mechanism is inhibition of force transmission due to promoting actin depolymerization. ${ }^{8}$ A third formal possibility for which there is no direct evidence in smooth muscles is to alter excitation mechanisms and calcium handling. HSP20 alters calcium signaling in cardiac muscle, but in that case enhances rather than inhibits contraction..$^{28,32}$ The actin depolymerization mechanism is supported by evidence that HSP20 interacts with HSP27 and with $\alpha$-actinin, ${ }^{46}$ and it interacts with 14-3-3 chaperones and the slingshot phosphatases. ${ }^{47}$ Slingshot proteins dephosphorylate cofilin, which allows cofilin to depolymerize F-actin. By keeping cofilin active, phosphorylated HSP20 may promote actin depolymerization, and therefore promote relaxation by uncoupling crossbridges from force transmitting structures.

The hypothesized mechanisms of HSP20-mediated relaxation were addressed in this study by: 1 . Showing that HSP20 phosphopeptide and a full length phosphorylation mimic inhibits contraction of intact canine and porcine tracheal smooth muscle (Figures 3, 4, and 9); 2. Showing the HSP20 phosphopeptide did not alter myosin phosphorylation (Figure 5) suggesting no gross effect on excitation mechanisms; 3. Showing that HSP20 weakens actin binding to myosin (Figure 7); 4. Showing that an HSP20 phosphorylation mimic disrupts F-actin in cultured cells (Figure 8). Altogether these results suggest HSP2 0 could act at sites in the actin cytoskeleton to disrupt force transmission as well as in actomyosin assemblies to disrupt actin-myosin binding. The effect on actomyosin appears to be limited to the initial binding reaction and not due to inhibition of other kinetic steps in the crossbridge cycle because average actin sliding velocity was not inhibited by either HSP20 or phosphorylated HSP20 (Figure 6). With respect to a third mechanism of inhibiting activation processes, the lack of effect on myosin light chain phosphorylation (Figure 5) argues against inhibition of calcium-activation of myosin light chain kinase, although more subtle effects on upstream steps in excitation and calcium handing cannot be ruled out.

\section{Cellular distribution and macromolecular complex formation}

We also explored the subcellular distribution of HSP20 to establish whether it was avidly associated with the cytoskeleton and whether there was any evidence of copolymerization with HSP27. The notion we were testing was that small heat shock proteins HSP27 and HSP20 act together to regulate actin filament dynamics. We found HSP20 in cultured ASM cells 


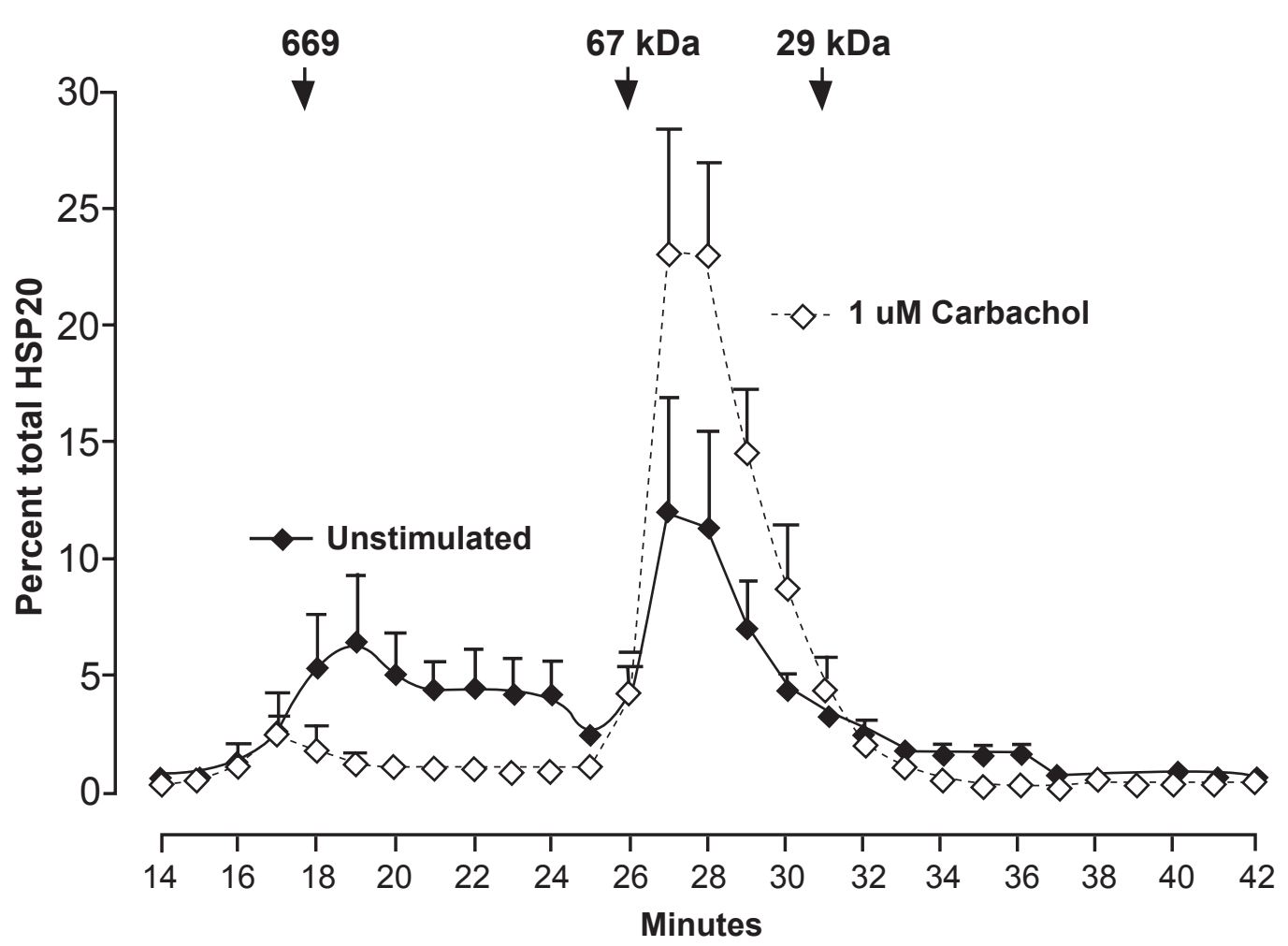

Figure II HSP20 associates dynamically with macromolecular complexes in airway smooth muscle. Homogenates of tracheal strips (unstimulated or stimulated with I $\mu$ M carbachol, I0 min) were clarified by centrifugation and the 100,000 × g supernatant subjected to gel filtration chromatography on a Superose I2 I0/200 GL column developed at $0.5 \mathrm{ml} / \mathrm{min}$. Fractions were assayed for HSP20 expression by immunoblotting with fluorescence detection. HSP20 content of each fraction was expressed as a percentage of the total HSP20 recovered in the $100,000 \times g$ supernatant. Purified protein molecular mass standards were analyzed to calibrate the column. $\mathrm{N}=7$.

is primarily soluble (Figure 10A), does not distribute solely to actin stress fibers (Figure 10B), and does not redistribute to a Triton-insoluble fraction upon treatment of tissues with isoproterenol (Figure 10C). This is similar to cultured cardiac myocytes in which HSP20 is cytosolic and upon heat stress redistributes to the nucleus. ${ }^{48}$ Using an established gel filtration chromatography method to study the dynamics of macromolecular complex formation we found that muscarinic activation of tracheal muscle caused a consistent shift in the size of HSP20 macromolecular complexes. Carbachol stimulation changed the size distribution of from large $(200-700 \mathrm{kDa})$ complexes to smaller $(<60 \mathrm{kDa})$ complexes (Figure 11) that were not further altered in size by subsequent treatment with isoproterenol (not shown). This protocol was meant to mimic the situation in vivo where airway constriction is antagonized by a short acting $\beta$-agonist. In that case, the bronchospasm probably induces redistribution of HSP20, but the $\beta$-agonist would not act by reversing the effect of carbachol. We cannot rule out changes in subpopulations of HSP20 complexes, such as in the vicinity of active sites of actin remodeling or at actomyosin crossbridges, but the data are not consistent with $\beta$-agonists reversing the major size redistribution induced by a contractile agonist. Nor does the data address the phosphorylation state of HSP20 in the various macromolecular species. The initial redistribution that occurs during contraction might be further modified by phosphorylation in subtle ways not detected by the relatively low resolution chromatography method.

In conclusion the results are consistent with phosphorylated HSP20 antagonizing airway smooth muscle contraction and contributing to bronchodilation by cyclic nucleotides. ${ }^{8} \mathrm{We}$ speculate that repression of HSP20 expression by complex mixtures of proinflammatory mediators may contribute to airway smooth muscle hyperreactivity, and that upregulation of expression may contribute to the efficacy of long-term treatment with $\beta$-agonists in therapy of asthma. New mechanistic data are consistent with HSP20 acting to reduce actomyosin crossbridge formation and to depolymerize F-actin, both of which would be expected to inhibit airway smooth muscle contraction and antagonize airway hyperreactivity.

\section{Acknowledgments}

Peptide synthesis was performed at the Nevada Proteomics Center supported by the University of Nevada, Reno, and funded by NIH Grant P20 RR-0164-05 from the 
Idea Networks of Biomedical Research Excellence (INBRE) Program of the National Center for Research Resources. The COBRE Proteomics core facility, supported by COBRE Grant 1P20RR018751, prepared purified contractile proteins. All studies were supported by NIH grants HL077726 (WTG) and HL080960 (CAS). We are grateful for the able technical assistance of Christine Cox, Shanti Rawat, Margaret Elorza, Michelle Deetken, and Glen Douglas.

\section{References}

1. Beall AC, Kato K, Goldenring JR, Rasmussen H, Brophy CM. Cyclic nucleotide-dependent vasorelaxation is associated with the phosphorylation of a small heat shock-related protein. $J$ Biol Chem. 1997;272(17):11283-11287.

2. Beall A, Bagwell D, Woodrum D, et al. The small heat shockrelated protein, HSP20, is phosphorylated on serine 16 during cyclic nucleotide-dependent relaxation. J Biol Chem. 1999;274(16): 11344-11351.

3. Rembold CM, O'Connor M, Clarkson M, Wardle RL, Murphy RA. Selected contribution: HSP20 phosphorylation in nitroglycerinand forskolin-induced sustained reductions in swine carotid media tone. J Appl Physiol. 2001;91(3):1460-1466.

4. Rembold CM, Foster DB, Strauss JD, Wingard CJ, Eyk JE. cGMPmediated phosphorylation of heat shock protein 20 may cause smooth muscle relaxation without myosin light chain dephosphorylation in swine carotid artery. J Physiol. 2000;524(Pt 3):865-878.

5. Woodrum D, Pipkin W, Tessier D, Komalavilas P, Brophy CM. Phosphorylation of the heat shock-related protein, HSP20, mediates cyclic nucleotide-dependent relaxation. J Vasc Surg. 2003;37(4):874-881.

6. Flynn CR, Komalavilas P, Tessier D, et al. Transduction of biologically active motifs of the small heat shock-related protein HSP20 leads to relaxation of vascular smooth muscle. FASEB J. 2003;17(10):1358-1360.

7. Flynn CR, Brophy CM, Furnish EJ, et al. Transduction of phosphorylated heat shock-related protein 20, HSP20, prevents vasospasm of human umbilical artery smooth muscle. J Appl Physiol. 2005;98(5):1836-1845.

8. Komalavilas P, Penn RB, Flynn CR, et al. The small heat shock-related protein, HSP20, is a cAMP-dependent protein kinase substrate that is involved in airway smooth muscle relaxation. Am J Physiol Lung Cell Mol Physiol. 2008;294(1):L69-L78.

9. Watanabe M, Yoshino Y, Morimoto S. Troponin I inhibitory peptide suppresses the force generation in smooth muscle by directly interfering with cross-bridge formation. Biochem Biophys Res Commun. 2003;307(2):236-240.

10. Brophy CM, Beall A, Lamb S, Dickinson M, Ware DJ. Small heat shock proteins and vasospasm in human umbilical artery smooth muscle. Biol Reprod. 1997;57(6):1354-1359.

11. Batts TW, Klausner AP, Jin Z, et al. Increased expression of heat shock protein 20 and decreased contractile stress in obstructed rat bladder. $J$ Urol. 2006;176(4 Pt 1):1679-1684.

12. Cross BE, O'Dea HM, MacPhee DJ. Expression of small heat shock-related protein 20 (HSP20) in rat myometrium is markedly decreased during late pregnancy and labour. Reproduction. 2007;133(4):807-817.

13. Shore SA, Moore PE. Effects of cytokines on contractile and dilator responses of airway smooth muscle. Clin Exp Pharmacol Physiol. 2002;29(10):859-866.

14. Amrani Y, Panettieri RA Jr. Cytokines induce airway smooth muscle cell hyperresponsiveness to contractile agonists. Thorax. 1998;53(8):713-716.

15. Gerthoffer WT. Calcium dependence of myosin phosphorylation and airway smooth muscle contraction and relaxation. Am J Physiol. 1986;250(4 Pt 1):C597-C604.
16. Hamann KJ, Vieira JE, Halayko AJ, et al. Fas cross-linking induces apoptosis in human airway smooth muscle cells. Am J Physiol Lung Cell Mol Physiol. 2000;278(3):L618-L624.

17. Rahman MS, Yang J, Shan LY, et al. IL-17R activation of human airway smooth muscle cells induces CXCL-8 production via a transcriptionaldependent mechanism. Clin Immunol. 2005;115(3):268-276.

18. Flynn CR, Smoke CC, Furnish E, et al. Phosphorylation and activation of a transducible recombinant form of human HSP20 in Escherichia coli. Protein Expr Purif. 2007;52(1):50-58.

19. Ikebe M, Hartshorne DJ. Effects of $\mathrm{Ca} 2+$ on the conformation and enzymatic activity of smooth muscle myosin. $J$ Biol Chem. 1985;260(24):13146-13153.

20. Ikebe M, Hartshorne DJ. Proteolysis of smooth muscle myosin by Staphylococcus aureus protease: preparation of heavy meromyosin and subfragment 1 with intact 20,000-dalton light chains. Biochemistry. 1985;24(9):2380-2387.

21. Ellison PA, Sellers JR, Cremo CR. Kinetics of smooth muscle heavy meromyosin with one thiophosphorylated head. J Biol Chem. 2000;275(20):15142-15151.

22. Smillie LB. Preparation and identification of alpha- and betatropomyosins. Methods Enzymol. 1982;85(Pt B):234-241.

23. Spudich JA, Watt S. The regulation of rabbit skeletal muscle contraction. I. Biochemical studies of the interaction of the tropomyosin-troponin complex with actin and the proteolytic fragments of myosin. $J$ Biol Chem. 1971;246(15):4866-4871.

24. Hooft AM, Maki EJ, Cox KK, Baker JE. An accelerated state of myosinbased actin motility. Biochemistry. 2007;46(11):3513-3520.

25. Negre-Aminou P, van Leeuwen RE, van Thiel GC, et al. Differential effect of simvastatin on activation of Rac(1) vs activation of the heat shock protein 27-mediated pathway upon oxidative stress, in human smooth muscle cells. Biochem Pharmacol. 2002;64(10): 1483-91.

26. Salinthone S, Singer CA, Gerthoffer WT. Inflammatory gene expression by human colonic smooth muscle cells. Am J Physiol Gastrointest Liver Physiol. 2004;287(3):G627-G637.

27. Trinklein ND, Murray JI, Hartman SJ, Botstein D, Myers RM. The role of heat shock transcription factor 1 in the genome-wide regulation of the mammalian heat shock response. Mol Biol Cell. 2004;15(3):1254-1261.

28. Fan GC, Chu G, Kranias EG. Hsp20 and its cardioprotection. Trends Cardiovasc Med. 2005;15(4):138-141.

29. Meeks MK, Ripley ML, Jin Z, Rembold CM. Heat shock protein 20-mediated force suppression in forskolin-relaxed swine carotid artery. Am J Physiol Cell Physiol. 2005;288(3):C633-C639.

30. Rembold CM, Meeks MK, Ripley ML, Han S. Longer muscle lengths recapitulate force suppression in swine carotid artery. Am J Physiol Heart Circ Physiol. 2007;292(2):H1065-H1070.

31. Pipkin W, Johnson JA, Creazzo TL, Burch J, Komalavilas P, Brophy C. Localization, macromolecular associations, and function of the small heat shock-related protein HSP20 in rat heart. Circulation. 2003;107(3): 469-476.

32. Islamovic E, Duncan A, Bers DM, Gerthoffer WT, Mestril R. Importance of small heat shock protein 20 (HSP20) C-terminal extension in cardioprotection. J Mol Cell Cardiol. 2007;42(4):862-869.

33. Brophy CM, Lamb S, Graham A. The small heat shock-related protein20 is an actin-associated protein. J Vasc Surg. 1999;29(2):326-333.

34. Bukach OV, Marston SB, Gusev NB. Small heat shock protein with apparent molecular mass $20 \mathrm{kDa}$ (HSP20, HSPB6) is not a genuine actinbinding protein. J Muscle Res Cell Motil. 2005;26(4-5):175-181.

35. Kato K, Goto S, Inaguma Y, Hasegawa K, Morishita R, Asano T. Purification and characterization of a $20-\mathrm{kDa}$ protein that is highly homologous to alpha B crystallin. J Biol Chem. 1994;269(21): 15302-15309.

36. Brophy CM, Dickinson M, Woodrum D. Phosphorylation of the small heat shock-related protein, HSP20, in vascular smooth muscles is associated with changes in the macromolecular associations of HSP20. J Biol Chem. 1999;274(10):6324-6329. 
37. Sugiyama Y, Suzuki A, Kishikawa M, et al. Muscle develops a specific form of small heat shock protein complex composed of MKBP/ HSPB2 and HSPB3 during myogenic differentiation. J Biol Chem. 2000;275(2):1095-1104.

38. Sun X, Fontaine JM, Rest JS, Shelden EA, Welsh MJ, Benndorf R. Interaction of human HSP22 (HSPB8) with other small heat shock proteins. J Biol Chem. 2004;279(4):2394-2402.

39. Zantema A, Verlaan-De VM, Maasdam D, Bol S, van der EA. Heat shock protein 27 and alpha B-crystallin can form a complex, which dissociates by heat shock. J Biol Chem. 1992;267(18): 12936-12941.

40. Batts TW, Walker JS, Murphy RA, Rembold CM. Absence of force suppression in rabbit bladder correlates with low expression of heat shock protein 20. BMC Physiol. 2005;5:16.

41. Macomson SD, Brophy CM, Miller W, Harris VA, Shaver EG. Heat shock protein expression in cerebral vessels after subarachnoid hemorrhage. Neurosurgery. 2002;51(1):204-220.

42. Gusev NB, Bukach OV, Marston SB. Structure, properties, and probable physiological role of small heat shock protein with molecular mass 20 kD (HSP20, HSPB6). Biochemistry (Mosc). 2005;70(6):629-637.
43. Salinthone S, Tyagi M, Gerthoffer WT. Small heat shock proteins in smooth muscle. Pharmacol Ther. 2008;119(1):44-54.

44. Gerthoffer WT, Trevethick MA, Murphy RA. Myosin phosphorylation and cyclic adenosine 3',5'-monophosphate in relaxation of arterial smooth muscle by vasodilators. Circ Res. 1984;54(1):83-89.

45. Gerthoffer WT. Dissociation of myosin phosphorylation and active tension during muscarinic stimulation of tracheal smooth muscle. J Pharmacol Exp Ther. 1987;240(1):8-15.

46. Tessier DJ, Komalavilas P, Panitch A, Joshi L, Brophy CM. The small heat shock protein (HSP) 20 is dynamically associated with the actin cross-linking protein actinin. J Surg Res. 2003;111(1):152-157.

47. Dreiza CM, Brophy CM, Komalavilas P, et al. Transducible heat shock protein 20 (HSP20) phosphopeptide alters cytoskeletal dynamics. FASEB J. 2005;19(2):261-263.

48. van de Klundert FA, de Jong WW. The small heat shock proteins Hsp20 and alphaB-crystallin in cultured cardiac myocytes: differences in cellular localization and solubilization after heat stress. Eur J Cell Biol. 1999; 78(8):567-472.
Cell Health and Cytoskeleton

\section{Publish your work in this journal}

Cell Health and Cytoskeleton is an international, peer-reviewed open access journal focusing on all aspects of cell structure and function contributing to normal physiology and cell health and exploring the pathogenesis of cell dysfunction leading to adverse conditions and disease in the organism. The journal welcomes papers covering original research,

\section{Dovepress}

basic science, reviews and evaluations, guidelines, expert opinion and commentary, case reports and extended reports. The manuscript management system is completely online and includes a very quick and fair peerreview system, which is all easy to use. Visit http://www.dovepress.com/ testimonials.php to read real quotes from published authors. 